\title{
People in Northern Bangladesh: Corona Pandemic 2020 Aftermath Action
}

\author{
Al-Amin Sarker \\ Lecturer in Economics \\ Open School, Bangladesh Open University, Bangladesh \\ E-mail: al_aminsarker@yahoo.com
}

\begin{abstract}
This paper is to explore Northern Bangladeshi People's standard of living scenario and how the standard of living could be developed in Rangpur Particularly. The most vulnerable groups in Northern Bangladesh are agricultural wage based marginal farmers; female-headed households and aged people. Their standard of living is very low with a low wage level. As the Coronavirus has become a pandemic in Bangladesh, the northern area is also included in Lockdown condition. The study has been conducted with a structured questionnaire and related statistical tools. The study suggests having more agro-based industrialization in that particular area after Lockdown condition and so on. It also suggests that to promote the standard of living of a particular area they need higher production with higher wage levels that will create higher income and a better standard of living.
\end{abstract}

Keywords: Standard of Living, Pandemic, Industrialization, Development, Northern Bangladesh.

\section{Introduction}

In the midst of crisis, one's judgments sometime were greedily twisted, their principles, desires, commitment are uncertain. In the midst of crisis, one's judgments sometime were greedily twisted, their principles, desires, commitment are uncertain. Everyone has his/her reasons, opinions, and arguments to elucidate for his own satisfaction or for the common good, their indifferences showcase, other may incline or decline to believe and pathetically breaking one's heart turning this simple misunderstanding to a debate but still at the end everyone are reunited, contributed their patriotic efforts, time, assistance for patriotism and nationalism (Masuhay, 2020).

The root causes of backwardness in the development of Rangpur are the agriculture-based economy, extreme poverty, high landless people, vast unemployment, etc. The northern region of Bangladesh is vulnerable to various natural calamities such as droughts, floods, Monga, etc that occur frequently and intensely than other parts of the country. Corona has added a new threat to Bangladesh and Northern Bangladesh is not out of its attack. The landless and poor people survive here on agricultural wages. The seasonal poverty is the near-famine situation of acute scarcity of employment during the Bangla month of BhadraKartik (September- November): It is commonly known as "Monga" or "abhab" (CARE,2005, Hasan 2006). Lack of employment opportunities is also greatly responsible for their low standard of living. If we can explore their potential productivity by providing higher wages to the local labor force establishing agro-based local Industries, their total production may be increased. Thus, their local demand may be increased. Further, their income and expenditure may be increased. Finally, their standard of living will be promoted.

\section{Objectives of the Research}

The objectives of the study are as follows-

- To identify the unemployed people in Northern Bangladesh

- To know the wage level of the local labor force

- To suggest for a better standard of living for them

\section{Research Questions}

Based on the objectives the study formulated some research questions as below-

- What is the employment status of Northern Bangladeshi people?

- What are the current wage level and productivity of that particular labor force?

- How standard of living may be increased? 


\section{Research Methodology}

Two villages named Kashimpur, Boirati of Kaliganj Upazila from Lalmonirhat district, and two villages named Baushmari, Pathardubi of Bhurungamari Upazila from Kurigram district have been purposively selected for primary data collection through household questionnaire survey and observations. Large-scale sample size was used to collect data. A total of 84 households were selected as samples from 820 households from the described four villages of the concerned region assuming a 90 percent confidence level by simple random sampling, Average; percentage, etc statistical tools have been used to analyze the collected data.

\section{Discussion and Findings}

The study emphasized on higher wage level of the people and if it can be implemented, a higher standard of living can be achieved with higher productivity and production not only just after Corona Pandemic but also for permanent development. To focus on the existing chart of Northern Bangladesh (Rangpur), at first, the study emphasized on the collected secondary data by the following discussions-

Table I. The daily average wage rate of Agriculture labor without and with food (in TK)

\begin{tabular}{|c|c|c|c|c|c|c|}
\hline \multirow[b]{2}{*}{ Region } & \multicolumn{3}{|l|}{2006} & \multicolumn{3}{|l|}{2011} \\
\hline & $\begin{array}{l}\text { With } \\
\text { food }\end{array}$ & $\begin{array}{l}\text { Without } \\
\text { food }\end{array}$ & Total & $\begin{array}{l}\text { With } \\
\text { food }\end{array}$ & $\begin{array}{l}\text { Without } \\
\text { food }\end{array}$ & Total \\
\hline Rangpur & I56 & I63 & 309 & 298 & 340 & 638 \\
\hline Rajshahi & 192 & 210 & 402 & 305 & 369 & 674 \\
\hline Dhaka & 224 & $26 I$ & 435 & 422 & 487 & 909 \\
\hline
\end{tabular}

Table 2. Regional disparity based on Industry, Transport and Communication sector

\begin{tabular}{|c|c|c|c|c|}
\hline \multirow[b]{2}{*}{ Division } & \multicolumn{4}{|c|}{ Industry } \\
\hline & Mean & Rank & C.V & Rank \\
\hline Rangpur & 724 & 3 & $27 \mathrm{I}$ & 3 \\
\hline Rajshahi & 835 & 2 & 260 & 2 \\
\hline Dhaka & 2382 & $\mathrm{I}$ & I53 & $\mathrm{I}$ \\
\hline
\end{tabular}

In the above table I and 2, it can be understood that Rangpur is very different and poor in terms of wage rate and industry disparity.

The present study identities are the standard of living, poverty eradication in the post-Corona situation in Northern Bangladesh.

Table 3. Present scenario of the low standard of living of North Bengal people based on some important variables.

\begin{tabular}{ll}
\hline Causes & Conditions \\
\hline Lack of distribution of resources & Income discrimination among the people \\
\hline Lack of Social Structures & Social distance and domination \\
\hline Lack of education and training & Unemployment \\
\hline Lack of small and medium enterprises & misuse of agricultural products \\
\hline Lack of Industrialization & Low Income of the labor force \\
\hline Lack of awareness & Increasing population and opportunities shortage \\
\hline Lack of rules and regulations & Social instability \\
\hline
\end{tabular}

The above table shows the present scenario of the low standard of living of North Bengal people based on some important variables.

Lack of Industrialization is a great factor for the low wage and standard of living in North Bengal historically. As the Coronavirus attacked almost every district of that region, people are completely unemployed in that zone as the rest of 
Bangladesh. Though Rangpur is also a corona hot spot, the temporary unemployment problem is a general consequence. But, concerning fact is that Rangpur is very far away from development and other social and economic opportunities. Under the circumstances, it is high time to establish mills and factories based on agricultural goods. Honorable Prime Minister Sheik Hasina has already declared to establish a Leather Industry (Tenary) in North Bengal. It is good news. But, agro-based other industries should be established at the same time to eradicate poverty in the long run permanently. Then all types of economic activities will mobilize the northern economy.

The study emphasized on Income for the better lives of the northern people. As the area is agro-based, so who are landless, sick, disabled, aged people, marginal women are the most sufferers. Blaikie et al. (2003) said that individuals and groups who are marginalized and powerless economically, politically, and socially are exposed to a double source of vulnerability. The study showed the double vulnerability in kurigram and Lalmonirhat is in an extreme situation. Most of the agro laborers are leading their life with a very low standard of living. Marginal women are deprived of proper wages and rights. They are less likely to have secure access to quality livelihoods and resources. A majority of the respondents (76\%) in the study area get lower wages than other parts of the country. The level of unemployment is $66 \%$ of the able-bodied persons who are willing to do work but cannot get a job in that region. Different NGOs and Govt. organizations came forward to enrich the situation, but these are very limited in action and most of the policy implementation scheme is inactive what ought to be. The study wanted to describe the industry's establishment of discrimination in the country. The northern region of Bangladesh is much more backward from this variable. Finally, the capital city Dhaka has become over and densely populated and pressured. Gazipur is also like that where a large number of populations came from Northern Bangladesh for job purposes. So, Govt. should take necessary steps like decentralization of industries and other establishments to have balanced job opportunities in the country and balanced development of the country emphasizing the northern region of the country. That could be the first initiative from north Bengal particularly. After the successful implementation of the idea, govt. can start it in the rest of the country further. The study further emphasized the truth of three variables positive relationship that is industrialization generates more Income and income generates a better standard of living.

\section{Conclusion}

Corona Pandemic attacked Bangladesh on $08^{\text {th }}$ March 2020. Though it has become a severe problem for the lives of human beings, the study thinks that it is a temporary problem. Time will solve the problem. The study gives importance to permanent stability in the Northern region. Northern Bangladeshi people are deprived of the British period. Still, now the region has not been industrialized. They are mostly depending on agriculture and as a result, they get low wages and so they deserve a low standard of living. Just agro-based industries can be a solution to their unlimited unhappiness. The conducted study considered the Corona pandemic as a temporary problem. After the Corona situation, the main focus should be agro-based industrialization in Rangpur to have more job opportunities and a better standard of living for Northern Bangladeshi people.

\section{References}

Blaikie, P., Cannon, T., Davis, I., \& Wisner, B. (20I4). At risk: natural hazards, people's vulnerability, and disasters. Routledge. CARE (Cooperative for Assistance and Relief Everywhere). (2005). Monga in northern Bangladesh. Retrieved from http://www.carebangladesh.org

Hasan, A. A. M. (2006). Looking into the institutional response to Monga. Bangladesh Legal Aid and Services Trust, Dhaka.

Islam, N., \& Noman, A. (20I5). Estimated Regional Disparity for Northern Bangladesh. IOSR Journal Of Humanities And Social Science, 20 (I), 59-63.

Masuhay, E. P. (2020). Adversaries on Covid-I9 Set Forth an Argument Onward To Educational Endeavor: Resulting To Develop a Modular Concept in the Learning Process. American International Journal of Social Science Research, 5(2), 26-37. https://doi.org/I0.4628I/aijssr.v5i2.520

\section{Copyrights}

Copyright for this article is retained by the author(s), with first publication rights granted to the journal. This is an open-access article distributed under the terms and conditions of the Creative Commons Attribution license (http://creativecommons.org/licenses/by/4.0/). 